\title{
Contemporary Pleonexia: The Birth Root of Nigeria Corruption and Social Instability
}

\author{
Vitalis Jafla Pontianus ${ }^{1, *}$ and Emeka Daniel Oruonye ${ }^{2}$ \\ ${ }^{1}$ Department of Sociology, Taraba State University \\ Jalingo, Nigeria \\ ${ }^{2}$ Department of Geography, Taraba State University \\ Jalingo, Nigeria \\ *Corresponding author's email: pontianus2004 [AT] gmail.com
}

\begin{abstract}
Nigeria has been described in recent time as the hub of poverty in the world. This came to many as a surprise because of the human and natural resources Nigeria as a nation has, if well harnessed she can occupy a central stage not only in Africa but the world at large. This article through discursive analysis tried to examine pleonexia, a psychological disposition that encourages people into an insatiable desire to amass wealth or community goods and services at the expenses of others. The findings of the study suggest that greed co uld be the main reason whycorruption has become part of the Nigerian society with all its consequences often felt by the common man. The study recommends that change of lifestyle through education, prosecution of public servants that are found guilty of embezzling public funds and the public mentoring of the younger generation could be the way forwardfor a better Nigeria.
\end{abstract}

Keywords--- Corruption, Community, Greed, Pleonexia and Social Ins tability

\section{INTRODUCTION}

The pas sion for selfish gratification in the amas sing of wealth, and the worship of money through fraudulent and deceptive tactics, have become an increasing ly visible and widely destructive phenomenon in the society. Pleonexia is a philosophical concept which roughly corresponds to greed, covetousness, or av arice. It is strictly defined as the in satiable desire to have what rightfully belongs to others (Lane, 2012). This connotation suggests what Ritenbaugh (1998) described as ruthless self-seeking and an arrogant as sumption that others and things exist for one's benefit.

The desire to acquire wealth and enriched one's self to the detriment of many others have informed what is perceived as corruption in Nigeria (Smith, 2009). Ranging from political leaders to business elite, private organization employers, government and private employees, public and private citizens; the agents promulgating corruption in our society tends to involve virtually everyone including religious and traditional leaders whom society have always presume have divine mandate to act for the good of all.

Olujobi (1999) classified wealth-producing resources into two broad areas namely tangible and intangible. The former consists of man, money, materials, and machinery, while the latter are made up of time and information. Olujobiciting the work of Drucker (1974) and Eas on (1988), referred to the human being as both the custodian of other resources, and the only active agent of production. Conversely, humanity is regrettably "the only active agent of thievery of other organizational resources in our custody". Corruption in Nigeria appears to be ubiquitous and takes many forms: from mas sive contract fraud to petty bribery; from straight-up embezzlement to complicated money laundering schemes; from pocketing the salaries of non-existent workers to steering plum jobs to relatives and friends. Some officials enjoy perquis ites so excessive that they are widely seen as a form of legalized corruption (Page, 2018).

Events in contemporary Nigeria poin ts to the fact that corruption is a cancer that has eaten into the fabric of every facet of our national life. Public officials demand payment of ransom before or/and after performing their legitimate functions. Businessmen and women short-change their customers through unfair dealings, while law-enforcement agents demand bribes, and collaborate with fraudulent elements in the society (Warf, 2016). Employee theft is a common occurrence in many org anizations. Could pleonexia be responsible for all these? 


\section{CONCEPTUAL CLARIFICATION}

\section{Pleonexia}

Scholars have no definitive translation for pleonexia (Balot, 2001). They provide a host of meanings for the word, though the rough consensus is "the unjust desire for more". English concepts relating to this broad interpretation include greed, covetousness, avarice, desire for plunder, imperialis $m$, and advantage taking at the detriment of others or the system The financial cris is of 2008 saw a world plaque by greed and in satiable desire to hoard away the essentials of the society at the detriment of many even when Lane (2012) observed that there has never been a deliberate act by the world to identify this fin ancial mis demeanour and give it, its rightful place in our social and economic narrative. Some scholars who study Plato and Aristotle (Mayhew, 1997, Smith, 2016) recognize that pleonexia meant 'the desire for more at the expense of another', but this meaning has not been broadly accepted in the academic world (Vlastos, 1973). Burghart (2015) argue that the best translation of the concept of pleonexia is "the desire to acquire more of something (whether that object is tangible, wealth, or intangible, honour or power) in a manner that either takes that good fromanother, or prohibits another fromaccessing or acquiring that good". Pleonexia, thus, is a parasitic form of greed. Greed is the selfish desire for more of an object, regardles s of how it is acquired (Cooey, 2004). Pleonexia specifies the means of acquisition in which other people suffer or are deprived.

\section{Pleonexia as Greed; Historical View}

The tenth commandment of the Judeo-Christian Decalogue as well as the entire Jewish ethical literature condemns and prohibits greed as the root of all social injustice. Covetousness destroys human relationships and leads to self-destruction, war, and other forms of social misdemeanours. The Jewish moral code advocates the restraint of the "me first" grasping impulse and strongly disapproves of the pride in acquiring riches. The ancient Athenians debated the social consequences of amas sing material wealth and believed that it had the tendency of corrupting character, breeding injustice and oppression, and could disrupt the natural order of society. As a result of that, they described greedy behaviour as pleonexia and considered the desire to have more than one's share as immoral and immature (Nikelly, 1992). The Hermian pers onality was described in Greek mythology as ambitious, seeking economic gain that exceeded reasonable limits (Brown, 1947). According to the myth, the god Hermes aggressively pursued affluence, stat us, and self-interest through manipulative, unscrupulous, and opportunistic practices. However, cupidity and rapacity were strongly frowned upon by the general population and were considered malad aptive and incompatible with virtue. These characteristics were thought to be signs of an atrophic superego that would eventually lead to perdition. Both Aristotle and Plato believed that greed does not bing satisfaction, it encourages destructive ambition and corruption, and it is a potential cataly st for civic breakdown (Balot, 2001). Similarly, the succeeding Romans thought that greed eroded personal and social values and destroyed collective life.

In medievalsociety, the production of goods met real needs and was relatively evenly spread throughout the community via family enterprises, local farms, social networks, and guilds. People produced or bartered for whatever was necessary and useful, a system that provided stability, solidarity, and intercommunal obligations (Robertson, 2001). At first, the Church renounced worldly wealth and preached the sanctity of poverty; however, as it amas sed vast properties bequeathed by the faithful to assure their place in thenext life, its authority shifted from the spiritual to the material, even degene rating into covetousness. Although the Church assisted the needy, its possessions were far over what was necessary for philanthropy (Coblentz, 1965). The Protestant ethic saw hard work as sacred and the amassing of wealth as a religious oblig ation that would assure salvation. This work ethic strengthened the capitalist spirit during the Industrial Revolution, which thrived on the production and accumulation of wealth (Oliver, 1998).

Adam Smith, in The Wealth of Nations written in 1776, held that the primary force in history is the insatiable desine to acquire wealth, a desire that he considered rational and morally legitimate. He argued that citizens own their abilities and thereby their acquisitions and are free agents not accountable to the needs of a larger society. Accordingly, possessions determine freedom, rights, and political obligations. This concept of "possessive individualism" became the basis of the market society (Macpherson, 1962).

John Locke renamed greed as "self-interest" whose advantages, he thought, would expand trade and bring pro sperity for every one (Hunt, 1990). Thomas Hobbes saw self-interest as an innate and positive as pect of human nature and the vehicle for creating wealth (Oliver, 1998). As the growth of a child's body is a sign of health, so is the increase in wealth an indication of a robust economy (Robertson, 2001).

Today, greed concentrates enormous power among a small, privileged group that amasses more wealth than is needed to live comfortably, while millions subsist below the poverty line (Sklar, 1995). Although in the movie Wall Street the statement is made that "greed is good" (Stone, 2010), economic growth created fromgreed benefits the prospering few and does not trickle into the pockets of the poor under the belief that a rising tide lifts all ships. Unregulated markets and the weak monitoring of trans actions provide incentives for financial malfeas ance and exces sive risk-taking behaviour guided by egregious monetary goals. These conditions create a greed-driven culture, infectious like a virus, causing markets to 
spiral out of control (Partnoy, 2003). The lure to greed also endang ers the mental health of the poor who experienceneedless suffering and neglect frombeing deprived of their needs (Ogilvy, 1999).

\section{SOCIAL ORIGIN OF PLEONEXIA}

Although needs can be defined as what is necessary for sustaining the basic comforts of living and for relieving suffering; wants, the essence of greed, are desires created by the social and economic environment (Dodd, 1994). Wants to have no quantitative limits and persons thereof are never fully satisfied (Robertson, 2001). Acquiring exorbitant wealth for its own sake lacks direction and distorts social roles and the purpose of economic activity (Dodd, 1994). Fromm (1961) argues that competitive for-profit marketing reduces the value of the individual to an exchange commodity; depersonalization and alienation from the social context result, and self-respect is undermined. Since self-worth is then measured by the degree of economic success, it follows that personal identity ultimately depends on the vagaries of the market which is beyond one's control. According to market dynamics, people are valued by what they have rather than by what they are or do (Coblentz, 1965).

When interpersonal relationships are guided by the marketing personality, the true identity of the person is obscured. Cushman (1990) maintains that human identity is, to a large extent, shaped by financial success, which becomes the index for self-worth. Economic and material values promote personal autonomy, detachment, and abounded self. Attitudes that separate the self from the social context undervalue the importance of socio-historical experiences, traditional beliefs, and community ties. The self becomes estranged, alienated, and 'lost' as it focuses on the status supposedly bestowed by their mere possession. Without social connectedness, life degenerates into an inauthentic existence of isolation, narcissism, selfindulgence, and 'neediness'. To satis fy these feelings of incompleteness and deficiency, the self-strives to ingest and merge with valued objects to restore itself and a vicious cycle is created.

Greed is an illusion that compensates for the void and the lack of meaning that a market-driven society promises to replenish. The belief that material self-interest is a ubiquitous and innate motive has been challenged and shown to be inculcated by the dominant economic and social institutions (media, workplace, schools) and through social learning and personal experience (Miller, 1999). Accordingly, people are erroneously taught by the prevailing economic system that self-interest is a social norm. Indeed, socio-historical evidence shows greed to be a cultivated behaviour orchestrated by economic and culturalvalues and neither inherited nor universal (Coblentz, 1965; Geertz, 1973; Dodd, 1994).

\section{THE CONCEPT OF CORRUPTION}

Divergent views on corruption agree that it is bad behaviour. Corruption may not be easy to define but, according to Tanzi (1998), it is generally not difficult to recognize when observed. The most simplified and popular de finition adopted by the World Bank is the abuse of public power for private benefit (Tanzi, 1998; Gray and Kaufmann, 1998). The different perspectives through which corruption is viewed, notwithstanding, a common ground of opinion conceives it as the perpetration of a vice against the public well-being.

Lipset and Lenz (2000), define corruption as an effort to secure wealth or power through illegal means - private gain at public expense. Tanzi (1995) defines it neutrally as the "intentional noncompliance with arm's length relationship aimed at deriving some advantages from this behaviour for ones elf or related individuals". This definition takes care of the exclusion of vital is sues, such as corruption in the private sector and priv ate activities. Tanzi believes that corruption occurs in every human endeav our and is often difficult to observe because acts of corruption do not ty pically take place in broad daylight (Tanzi, 1998).

Alatas (2006), briefly defines corruption as a situation where two people can act to increase their pay-off at the expense of a third pers on. This does not mean, however, that an individualcannot perpetrate the act. The point here is that, most often, it takes at least two people to perfect an act probably conceived by an individual. Gray and Kaufmann (1998) define the acts of corruption to inclu de bribery and extortions, which necessarily involve at least two parties and other malfeasances that a public official can carry out alone including fraud and embezzlement. To them, it manifests in governmental activities through the appropriation of public as sets for private use and embezzlement of public funds by politicians and high -level officials. This description combines political and bureaucratic officials. People might as sume that only politicians in government are corrupt. Most often, bureaucrats provide the templates for perfected corruption. Most corrupt practices are only exposed by bureaucrats when they are excluded from sharing in the proceeds. Thus, corruption in government cannot be a unilateral action. Therefore, corruption manifests in all facets of governmental activities -contracts, the allocation of benefits, collection of public revenues, and judicial pronouncements. Officials involved in performing these duties partake at one stage or the other, in the abuse of the processes.

Dike (2002) contends that corruption is a function of great inequality in wealth distribution, the perception that political offices are the primary means of gaining access to wealth, the conflicts between changing moral codes, the weakness of social and governmental enforcement mechanismand a lack of a strong sense of national community. 
Gray and Kaufmann (1998), identify seven factors that engender corruption. These are the value of wages and salaries, the presence of strong opportunities and awareness of how to perpetuate corruption, weak measures against accountability, population, natural resources wealth, lack of political will, and indecisive pressure and assistance from the global community. These corruption-enhancing factors vary from one culture to the other and from one political system to the other. One key point to note, however, is that it is possible to identify an act of corruption when it is perpetrated irres pective of cultural or political background. Corrupt practices are obvious.

\section{PLEONEXIA AND CORRUPTION IN NIGERIA}

Pleonexia in Nigeria has done a con spicuous crime of enlarging the fortune of the rich while le aving the poor mas ses in an impoveris hed condition. Religiously, everyone wants to amass wealth at the expense of their religious values and beliefs; all these because of greed, and religion have been seen in many quarters and among many religious groups in Nigeria as an easy way to wealth (Hugo, 2011). Educationally, greed has done an unquantifiable harm of making everyone, both the teachers and the students, strive with the last drop of their blood, to undertake easy-way outs, regardless of the means, provided money will always be there. Ipsofacto, the rate of sub-standard and half-baked graduates being produced by the Nigerian educational in stitutions annually is on competitive increase and surmount hope of our educational system(Oni, 2013). All of thes e have led to a single term, 'corruption' thats eems to have eaten deep into the Nigerian society and has become a 'legitimate' way of life.

Obasanjo (2004) enumerated the various forms of corruption to include advance-fee fraud (known as 419), money laundering, unconventional and fraudulent trade practices, misappropriation or diversion of funds, kickbacks, under and over-invoicing, bribery, fals e declarations, abuse of office, and collection of illegal tolls. Other contextual meanings include the impairment of integrity, virtue or moral principles, and any unauthorized use of resources for private gain. The causal factors of all these could be attributed to cultural and social values, conflicting signals, and loyalties arising from societies undergoing significant economic, political, or psychological transitions.

Locating corrupt activities within the domain of public office, Agbaje (2004) listed pervasion of public rules and misuse of official power for selfis motive, and the fru stration of the electoral process to make free and fair election impossible. Other dimens ions of corruption, according to Agbaje, are the deliberate refusal to declare one's assets on the assumption and expiration of public office and using one's official status to prevent thead ministration of justice.

Amundsen (2010) provides useful descriptions of the types of corruption in Nigeria. The report states that corruption in Nigeria serves two main purposes:

i. To extract rents from the state, which includes rent-seeking behaviour in the form of embezzlement, abuse of power, bribery, nepotism, and cronyism, among others; and

ii. To preserve power, that is, to ensure that an individual maintains his/her position of power or gains accessto such a position through activities such as electoral corruption, judicial corruption, or the distribution of public jobs. Concerning the magnitude, studies suggest that public funds of about US $\$ 300$ and US $\$ 400$ billion have been lost to corruption since Nigeria became independent in 1960 (Global Witness, 2012a). General Abacha alone allegedly embezzled billions of dollars from the Central Bank of Nigeria between 1993 and 1998 (US Department of Justice, 2014), which demons trates the magnitude of parasitic greed.

Other examples illus trate how Nigerian politicians and subsequent heads of the national oil company have abused their power and control over the oil industry to divert public money (Global Witness, 2012b). For instance, a UK court found former governor of the oil-rich state Delta, James Ibori, guilty of laundering money stolen from Nigerian public coffers. According to Global Witness, while his official salary was only $£ 4,000$ per year (just under US $\$ 7,000$ ), he managed to buy several houses around the world, including one in the UK valued at £2.2 million (US\$2 million), owns luxury cars and a private jet, in addition to holding bank accounts in several other countries (Global Witness, 2012b).

Issues related to nepotis mand crony ismhave been a common feature of Nigerian society (Ekanem\& Ekefren as cited in Martini, 2014) and as such are also widely addressed in the literature (Ndem, 2012). There is evidence that family ties and personal connections play an important role in the appointment of individuals to public positions, as well as conceming promotions and remuneration. Government institutions are constantly filled according to ethnicity, religion, or political affiliation rather than merit and profes sional qualifications (Okafor as cited in Martini, 2014). For instance, a former Minis ter of the Federal Territory appointed his wife and children to positions within the land adminis tration (Ekanem \& Ekefren as cited in Martini, 2014). There is also evidence that well-connected individuals are appointed to public positions without ever appearing to work (ghost workers), and that there is an inflation in the number of public jobs created to accommodate ethnic and politicalgroups, as well as to reward officials who turn a blind eye to irregularities (All Africa, 2013). According to media reports, there have been recruitment-related scandals in several federal bodies - particularly in those regarded as "lucrative", such as the NNPC, the customs services, the army, and financial institutions (All Africa, 2013). 
A newspaper article on corruption in Nigeria emphasizes that "losing power in Nigeria means losing access to vast revenues, especially fromthe opaque oil sector. It also raises the chances of being prosecuted should any new government decide to crack down on graft" (Financial Times, 2013). Within this framework, there is also evidence that corruption takes place to preserve or access power (Amundsen, 2010). This includes undue influence over the selection of candidates and the election process, complete dis regard for campaign financing laws, as well as a deeply entrenched patronage system. It also includes ensuring that anti-corruption agencies and the judicial system do not investigate or prosecute officials involved in mis management and wrongdoing, so that they can remain in power and can continue extracting rents from the state. As such, the main forms of corruption that have been taking place as a means of power preservation include political corruption (i.e. electoral corruption, illegal campaign financing and corruption within political parties) and judicial corruption, including undueinfluence and bribery of public prosecutors, magistrates and court staff.

The predis posing factors to corrupt practices according to Olujobi (1999) are as follows:

- An irrational, strong and perverse urge to break rules, beat the system, and out of control, even for the fun of it.

- Might is right and the use of double standard.

- Perception of society as notcaring or providing equalopportunities for self-development.

Certain behavioural aberrations resulting from the above are being rationalized with business maxim viz: greed makes the world go around and he who pays the piper dictates thetune (Adewunmi, 1999).

\section{PLEONEXIA AND SOCIAL INSTABILITY IN NIGERIA}

Pleonexia no doubt breeds all forms of corruption and the direct connection between corruption and social instability can be made easily. In its website, the ICPC (Independent Corrupt Practices and other Related Offences Commission) notes, "Corruption in Nigeria undermines democratic ins titutions, retards economic developmentand contributes to government instability. Corruption attacks the foundation of democratic institutions by distorting electoral processes, perverting the rule of law, and creating bureaucratic quagmires whose only reason for existence is the solicitation of bribes" (Nwankwo, 2014). In other words, corruption leads to underdevelopment. When merit is thrown overboard or when the resources of the State are diverted into private pockets, instead of used for public good such as job creation, the result is mediocrity, unemployment, and an army of restive young people, alienated from the State. These could be taken to crime or be recruited for anti-State activities. The net result is insecurity and instability.

During Abacha's regime, it is common knowledge that the Nigerian economy and treasure were merciles sly crippled and diverted to personal use (US Department of Jus tice, 2014). Yet unemployment abounds because funds that would enable youth employment have been diverted to private pockets by those at the helm of affairs. Consequently, the unemployed graduates opt for various kinds of moral evil like armed robbery, prostitution, bribery, kidnapping, and cheating, to make ends meet and so creating unrest and instability in the society.

At the Federal, State, Local Government and Ward levels, governance is synonymous with the distribution of rent and other resources. Because of the enormous resources involved, capturing and retaining political power became a 'do-or-die affair'. Overseeing the dis tribution of the rent, the political office holder often allocates these resources according to their subjective preferences and for their benefit. They sometimes support interventions that do not maximize the benefit for all but to themselves, their supporters and cronies. In a transliteration of the Igbo saying, 'the officeholder is the one holding the yam and the knife, and he or she slices off and distributes to each as much as he pleases'. The discourse is therefore not in terms of anybody's right or due as enshrined in the 'international code of best practices' but in terms of what is pleasing to 'Oga' or 'Madam' (Nwankwo, 2014). These officeholders, therefore, become patrons and the citizenry become their clients and their relationship is not regulated by codified rights and duties but by the code of privileges and inducements given for personal benefits. It is such a relationship that is variously described as patrimonialism or clientelis $m$. That is, the relationship between the State and its functionaries on the one hand, and the rest of the polity, on the other hand, is not what it should be. Instead of being regulated by rights and duties, instead of the allocation of resources and dis tribution of welfare being guided by the common good, rather personal and ethnic considerations prevail.

What is being described above is the corruption of the State, the subversion of what the State should be and how it should operate. Worse still, the dynamics described aids and abets corruption in the wider society. Other in stitutions are weakened and infused with similar rationality. The net result is an emphasis on and mobilization of certain forms of identities viz ethnicity, geopolitical, religious, etc. - for the attainment of personal, sectional, and interests at the expense of the common good. This creates instability in the polity as these forms of identities are often brazenly deployed in the contestation for power, control, and other privileges.

\section{CONCLUSION}

This study has examined contemporary pleonexia as the birth root of Nigerian corruption and social instability. The finding of the study reveals that classical Greek authors understand the concept of pleonexia to mean the desire or act to gain 
something (political power, material goods, status) in such a manner that it limits another's ability to gain access to that same resource. It was a cons cious decision on the part of one actor (an individual, a group, or a city) to operate in such a way that would seek to gain on the one side and impose a loss on another.

Pleonexia is not only an anti-social and humane vice but the hatching source of other numerous anti-social vices and criminal acts. By implication, greed as a vice did not develop today. It has been ab initio in man's existence and has never ceased from its function of giving birth to other inhumane vices. A glaring instance could be drawn from various happenings that have been evident in various sectors of lives, both nationally and internationally recognized ones.

Nigeria as a society has a whole lot of manifestations of greed in multifarious manifolds of life: politically, socially, culturally, economically, and surprisingly enough, in the religious sector. Politically, Greed has become an enchantment to our entire leaders and their cohorts, thereby letting themperceive it as joie de vivre to life. This sector is where the effect of greed as the root cause of our societal menace is pronounced. Ever since she had her independence from the colonialists on 1st October 1960, Nigeria has been battling from one political crisis to another till today and the battle seems to get worse with the rising level of living standard in which most Nigerians want to live in affluence at the expense of many. This attitude has made life more difficult for the common man and woman.

\section{RECOMMENDATIONS}

i.Given that greed is to a large extent due to social learning, and since insight alone without action is ineffective, changes can be motivated on the conscious level of Nigerians by focusing on ego development without psychodynamic explorations.

ii.The antidote to greed according to the ancient Greeks is fostering character and refining excellence and virtue through education, raising moral consciousness about the ultimate human good, and harmonizing the appetites with reason and temperance.

iii.A sense of freedom from corruption will be achieved in Nigeria when intemperate and social behaviour is replaced with a reciprocal concern for others and the dialectic of the mutuality of needs.

iv. Equality before the law and prosecution of public servants that have embezzled public fund s. This can be achieved by consolidating the activities of economic and financial crime commission (EFCC) in such a way that cases are expediate and offenders prosecuted in no fartime.

v.Public figures and celebrities should see themselves as models of mode st lifestyle and simplicity.

\section{REFERENCES}

- Adewunmi, W. (1999). Professionalis mand Ethics in Banking. Management in Nigeria, 35(1).

- Agbaje, E. B. A. (2004). Corruption, Accountability and Good Governance - Reflections on Governance in Nigeria's fourth Republic 1999 - 2003. International Review of Politics and Development, 2(2).

- Alatas. V. (2006). Gender and Corruption: Insight from an Experimental Analysis. Retrieved from https://www.economics.unimelb.edu.au/lcameron/papers/gender/pdf

- All Africa, (2013). Nigeria: The Rise in Federal Recruitment Scandals. Retrieved from http://allafrica.com/stories/201301070915.html

- Amundsen, (2010). Good Governance in Nigeria. A Study in Political Economy and Donor Support. Retrieved from $\mathrm{http}: / /$ www.norad.no/en/tools andpublications/publications/publication?key=203616

- Balot, R. (2001). Greed and Injustice in Classical Athens. Princeton: Princeton University Press.

- Bello, A. (2014). Gift-Giving, Anti-Bribery Laws, and the Nigerian Constitution: Matters Arising. Journal of African Law, 58(2), 278-302. Retrieved October 15, 2020, from http://www.jstor.org/stable/24735217

- Brown, N. O. (1947). Hermes the Thief: The Evolution of a Myth. Madis on, WI: University of W is consin Press.

- Burghart, D. W.(2015). How things fall apart: Pleonexia, parasitic greed, and decline in Greek thought from Thucydides to Polybius (Doctoral thesis, University of Maryland, College Park). Retrieved from https://drum.lib.umd.edu/bitstream/handle/1903/16416/Burghart umd 0117E 15889.pdf

- Coblentz, S. A. (1965). Avarice: A History. Washington, DC: Public Affairs Press.

- Cooey, P. (2004). Christian Perspectives on Overcoming Greed in a Consumeristic Society: Buying Fear as Collusion with Greed versus an Economy of Grace. Buddhist-Christian Studies, 24,39-46.

- Cushman, P. (1990). Why the self is empty: Toward a historically situated psychology. American Psychologist, 45, 599-611.

- Dike, V. (2002). Corruption in Nigeria: A New Paradigm for Effective Control. Retrieved from://www.a http fricaneconomicanaly sis.org/articles/gen/corruptiondike/htm.html

- Dodd, N. (1994). The Sociology of Money. New York, NY: Continuum.

- Financial Times, (2013). Patronage politics boosts demands for dollars in Nigeria. Retrieved from http://www.ft.com/intt/cms/s/0/78ce68f4-2f2e-11e3-8cb2-00144feab7de.htm

- Fromm, E. (1961). Man, for Himself. New York, NY: Holt, Rinehart \& Winston. 
- Geertz, C. (1973). The Interpretation of Cultures. New York, NY: Basic Books.

- Global Witness, (2012a). Global Witness Submission to International Development Select Committee Inquiryon Tax and Development. Retrieved fromhttp://www.globalwitness.org.

- Global Witness, (2012b). Rigged? The Scramblefor Africa 's Oil, Gas and Minerals. Retrieved from https://globalwitness.org.

- Gray, C. W, \& Kaufmann, D. (1998). Corruption and Development. Retrieved from http://www.worldbank.com/fandd/english/0398/articles/020398/html

- Hugo, A. (2011) The Man who Forgave God: Faces of 419 scam, South Africa, Tsumele Publishers.

- Hunt, G. M.(1990), Philosophy and Politics, Cambridge, Cambridge University Press.

- Lane, M. (2012). From Greed to Glory: Ancient to Modern Ethics - and Back Again? In Eco-Republic: What the Ancients Can Teach Us about Ethics, Virtue, and Sustainable Living (pp. 29-46). Princeton; Oxford: Princeton University Press. doi:10.2307/j.ctt1r2df3.7

- Lipset, S. M, \& Lenz, G. S. (2000). Corruption, Culture, and Market in Lawrence Harrison and Samuel P. Huntington, eds., Culture Matters. New York: Basic Books.

- Macpherson, C. B. (1962). The Political Theory of Possessive Individualism. Oxford: Oxford University Press.

- Martini, M. (2014). Nigeria: evidence of corruption and the influence of social norms. Retrieved from https://www.u4.no/publications/nigeria-evidence-of-corruption-and-the-influence-of social-norms.pdf

- Mayhew, R. (1997). Aristotle's criticism of Plato's Republic. Oxford: ROWMAN \& LITTLEFIELD Publis hers. Inc.

- Miller, D. T. (1999). The normof self-interest. American Psychologist, 54: 1053-1060.

- Ndem, B. (2012). Social Capital, Corruption, and Economic Growth in Nigeria: A Case Study of Some Contracts Awarded by Niger Delta Development Commission in Akwa Ibom and Cross River State. Retrieved from http://pakacademicsearch.com.

- Nikelly, A. G. (1992). The pleonexia personality: a new provisional personality disorder. Individual Psychology, $48,253-260$.

- Nwankwo, N. L. (2014). Corruption, the state, and the challenge of social instability in Nigeria. Unizik Journal of Art and Humanities, 14(3), 45-64. http://dx.doi.org/10.4314/ujah.v14i3.4

- Obasanjo, O. (2004). Tackling Corruption and Promoting Transparency and Accountability, Proceedings of National Economic Empowerment and Development Strategy. NationalPlanning Commission, Abuja, Nigeria.

- Ogilvy, J. (1999). Greed. In Solomon RC (ed), Wicked Pleasures: Meditations on the Seven 'Deadly' Sins. Lanham, MD: Rowman \& Littlefield.

- Oliver, M. (1998). History of Philosophy. New York, NY: Barnes \& Noble.

- Olujobi A.O. (1999) Employee Theft:A Veritable Threat to Corporate Survival. Managementin Nigeria, 35(1).

- Oni, S. (2013), Challenges and Prospects in African Educational system, USA, Trafford Publishing.

- Onyeso, C. B. (n.d.). Greed: the root cause of Nigerian menace. Retrieved from https://www.academia.edu/19276033/GREED THE ROOT CAUSE OF NIGERIA MENACE

- Page, M. (2018). A NEW TAXONOMY FOR CORRUPTION IN NIGERIA (pp. 3-5, Rep.). Carnegie Endowment for International Peace. doi:10.2307/resrep21006.5

- Partnoy, F. (2003). Infectious Greed. New York: Times Books.

- Ritenbaugh, W. J. (1998). The Tenth Commandment. Forerunner, "Personal". Retrieved August 1, 2020, from https://www.cgg.org/index.cfm/library/article/id/301/the-tenth-commandment.htm

- Robertson, A. F. (2001). Greed: Gut Feelings, Growth, and History. Cambridge: Polity Press.

- Sklar, H. (1995). Chaos or Community? Boston, MA: South End Press.

- Smith, D. (2009). The Paradoxes of Popular Participation in Corruption in Nigeria. In Rotberg R. (Ed.), Corruption, Global Security, and World Order (pp. 283-309). Brookings Institution Press. Retrieved September 14, 2020, from http://www.jstor.org.ucc.idm.oclc.org/stable/10.7864/j.ctt6wpgj4.14

- Smith, T. (2016). Love of The Good as The Cure For Spiritedness In Plato's "Republic". The Rev iew of Metaphysics, 70(1), 33-58. Retrieved October 16, 2020, from http://www.jstor.org.ucc.idm.oclc.org/stable/44806894

- Stone, O. (Director). (2010). Wall Street: Money Never Sleep [DVD]. USA: 20th Century FoxHome Video.

- Tanzi, V. (1995). Corruption, Arm 's-Length Relationship and Market in Fiorentian Gianluca and SamPeltzman, eds, The Economics of Organized Crime, Cambridge: Massachusetts: Cambridge University Press.

- Tanzi, V. (1998). Corruption Around the World:Causes, Consequences, Scope, and Cures. IMF Staff Papers, 45(4). Retrieved fromhttp://www.imf.org/external/pubs/FT/staffp/1998/12-98/pdf/tanzi.pdf

- United States Department of Justice, (2014). U.S. Freezes More Than \$458 Million Stolen by Former Nigerian Dictator in Largest Kleptocracy Forfeiture Action Ever Brought in the U.S. Retrieved from 
http://www.justice.gov/opa/pr/us-freezes-more-458-millionstolen-former-nigerian-dictator-largest-kleptocracyforfeitur

- Vlastos, G. (1973). Platonic Studies. Hartford, CN: Princeton University Press.

- Warf, B. (2016). Global geographies of corruption. GeoJournal, 81(5), 657-669. Retrieved October 17, 2020, from http://www.js tor.org/stable/44076432 